Prepared in cooperation with the Indiana Department of Transportation

\title{
Flood-Inundation Maps for the White River near Edwardsport, Indiana
}

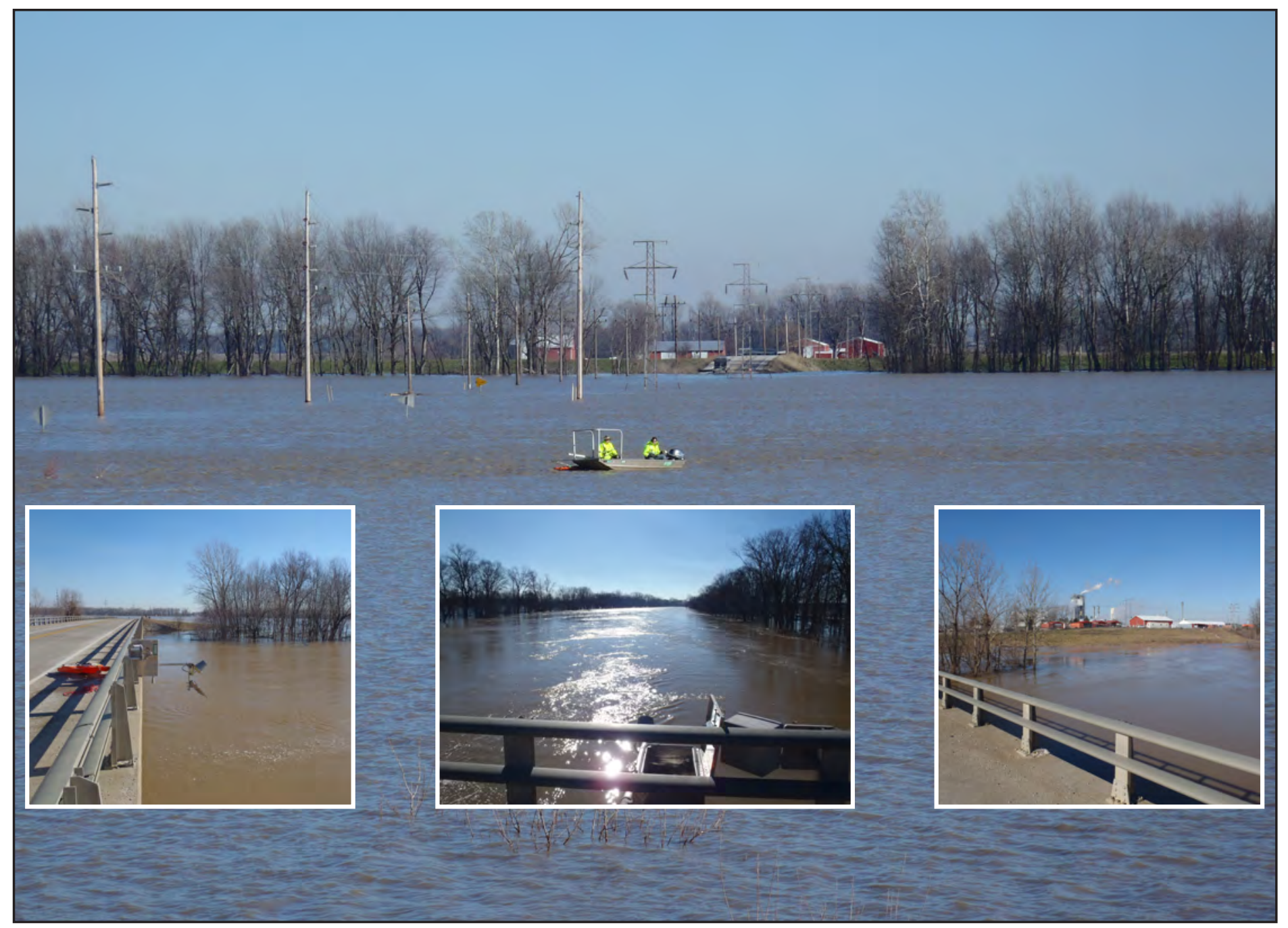

Scientific Investigations Report 2014-5219 
Cover photos: Views from State Road 358 bridge over White River near Edwardsport, IN, taken on January 18, 2013 by Paul Baker of the U.S. Geological Survey. 


\section{Flood-Inundation Maps for the White River near Edwardsport, Indiana}

By Kathleen K. Fowler

Prepared in cooperation with the Indiana Department of Transportation

Scientific Investigations Report 2014-5219 


\title{
U.S. Department of the Interior SALLY JEWELL, Secretary
}

\section{U.S. Geological Survey Suzette M. Kimball, Acting Director}

\author{
U.S. Geological Survey, Reston, Virginia: 2014
}

For more information on the USGS - the Federal source for science about the Earth, its natural and living resources, natural hazards, and the environment, visit http://www.usgs.gov or call 1-888-ASK-USGS.

For an overview of USGS information products, including maps, imagery, and publications, visit http://www.usgs.gov/pubprod.

To order this and other USGS information products, visit http://store.usgs.gov.

Any use of trade, firm, or product names is for descriptive purposes only and does not imply endorsement by the U.S. Government.

Although this information product, for the most part, is in the public domain, it also may contain copyrighted materials as noted in the text. Permission to reproduce copyrighted items must be secured from the copyright owner.

Suggested citation:

Fowler, K.K., 2014, Flood-inundation maps for the White River near Edwardsport, Indiana: U.S. Geological Survey

Scientific Investigations Report 2014-5219, 11 p., http://dx.doi.org/10.3133/sir20145219.

ISSN 2328-0328 (online) 


\section{Contents}

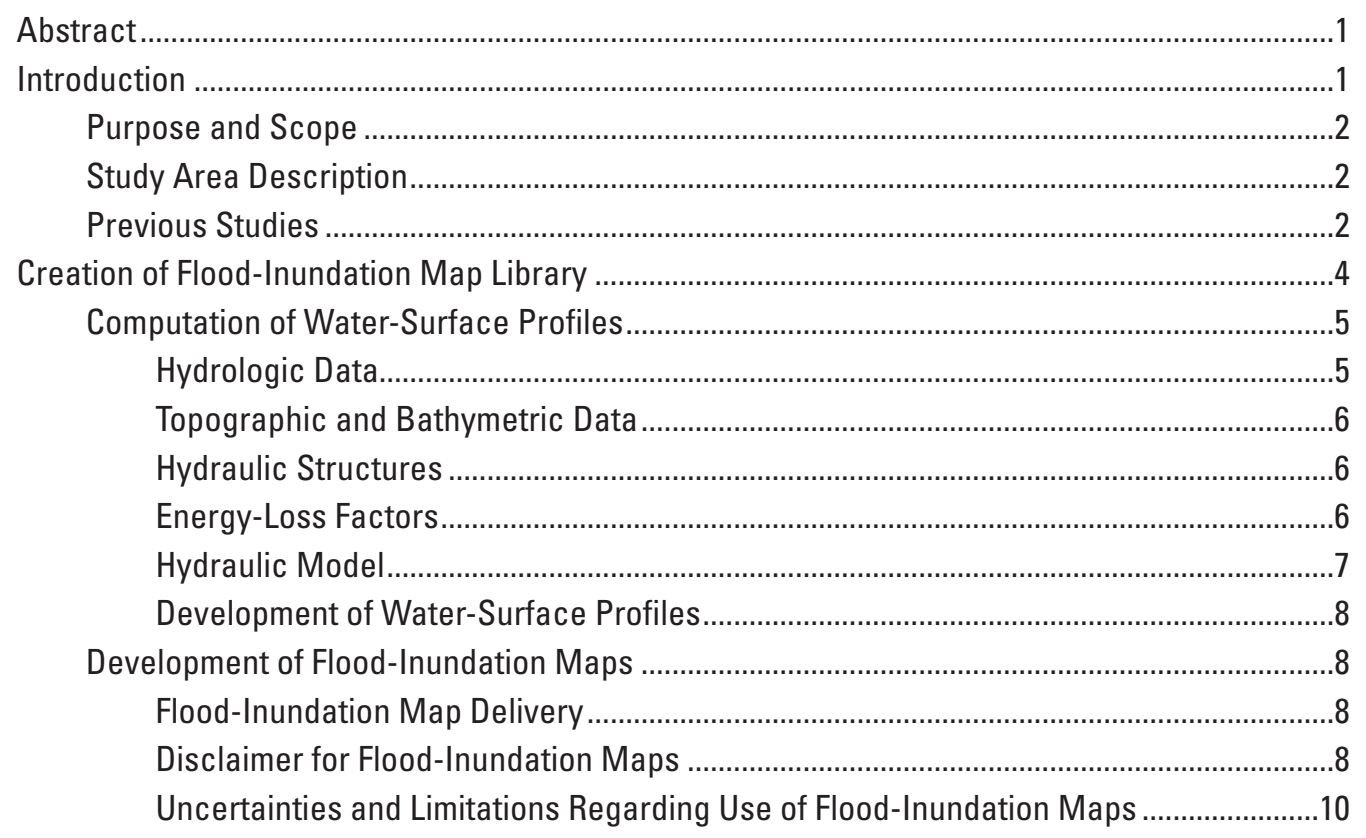

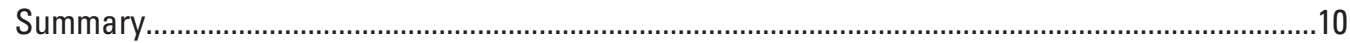

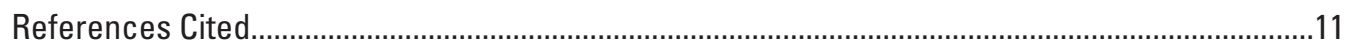

\section{Figures}

1. Map showing location of study reach for the White River near Edwardsport, Indiana; location of U.S. Geological Survey streamgage; and location of National Weather Service forecast sites .........................................................................

2. Flood-inundation map for the White River near Edwardsport, Indiana, corresponding to a stage of 29.9 feet at the U.S. Geological Survey streamgage

\section{Tables}

1. U.S. Geological Survey streamgage information for White River near Edwardsport, Indiana.

2. Coordinated discharges for selected annual exceedance probabilities for White River near Edwardsport, Indiana.

3. Estimated discharges for corresponding stages and water-surface elevations at U.S. Geological Survey streamgage 03360730 used in the hydraulic model of the White River near Edwardsport, Indiana.

4. Calibration of hydraulic model to target water-surface elevations at U.S. Geological Survey streamgage on White River near Edwardsport, Indiana.

5. Calibration of hydraulic model to water-surface elevations at selected locations along the White River for the flood of April 24, 2013 


\section{Acknowledgments}

The authors wish to thank the many local, State, and Federal agencies that have cooperated in the funding for the operation and maintenance of the gage used for this study, especially the National Streamflow Information Program. Special thanks are given to Indiana Department of Transportation for their cooperation in this study and to the National Weather Service for their continued support to the U.S. Geological Survey flood-inundation mapping initiative.

\section{Conversion Factors}

Inch/Pound to SI

\begin{tabular}{|c|c|c|}
\hline Multiply & By & To obtain \\
\hline \multicolumn{3}{|c|}{ Length } \\
\hline foot $(\mathrm{ft})$ & 0.3048 & meter $(\mathrm{m})$ \\
\hline mile (mi) & 1.609 & kilometer (km) \\
\hline \multicolumn{3}{|c|}{ Area } \\
\hline square mile $\left(\mathrm{mi}^{2}\right)$ & 2.590 & square kilometer $\left(\mathrm{km}^{2}\right)$ \\
\hline \multicolumn{3}{|c|}{ Flow rate } \\
\hline cubic foot per second $\left(\mathrm{ft}^{3} / \mathrm{s}\right)$ & 0.02832 & cubic meter per second $\left(\mathrm{m}^{3} / \mathrm{s}\right)$ \\
\hline \multicolumn{3}{|c|}{ Hydraulic gradient } \\
\hline foot per mile (ft/mi) & 0.1894 & meter per kilometer $(\mathrm{m} / \mathrm{km})$ \\
\hline
\end{tabular}

Vertical coordinate information is referenced to either (1) stage, the height above an arbitrary datum established at a streamgage; or (2) elevation, the height above North American Vertical Datum of 1988 (NAVD 88).

Horizontal coordinate information is referenced to the North American Datum of 1927 (NAD 27). 


\title{
Flood-Inundation Maps for the White River near Edwardsport, Indiana
}

\author{
By Kathleen K. Fowler
}

\begin{abstract}
Digital flood-inundation maps for a 3.3-mile reach of the White River near Edwardsport, (Ind.), were created by the U.S. Geological Survey (USGS) in cooperation with the Indiana Department of Transportation. The inundation maps, which can be accessed through the USGS Flood Inundation Mapping Science Web site at http://water.usgs.gov/osw/flood inundation/, depict estimates of the areal extent and depth of flooding corresponding to selected water levels (stages) at USGS streamgage 03360730, White River near Edwardsport, Ind. Near-real-time stages at this streamgage may be obtained from the USGS National Water Information System at http:// waterdata.usgs.gov/ or the National Weather Service Advanced Hydrologic Prediction Service at http:/water.weather.gov/ ahps/, which also forecasts flood hydrographs at this site (site EDWI3).

Flood profiles were computed for the White River near Edwardsport reach by means of a one-dimensional step-backwater model developed by the U.S. Army Corps of Engineers. The hydraulic model was calibrated by using the most current stage-discharge relations at USGS streamgage 03360730, White River near Edwardsport, Ind., and high-water marks from the flood of April 2013. The calibrated hydraulic model was then used to determine 19 water-surface profiles for flood stages at approximately 1-foot intervals referenced to the streamgage datum and ranging from bankfull to the highest stage of the current stage-discharge rating curve. The simulated water-surface profiles were then combined with a geographic information system digital elevation model to delineate the area flooded at each water level.

The availability of these maps, along with Internet information regarding current stage from the USGS streamgage 03360730 White River near Edwardsport, Ind., and forecasted stream stages from the National Weather Service, provides emergency management personnel and residents with information that is critical for flood response activities such as evacuations and road closures, as well as for post-flood recovery efforts.
\end{abstract}

\section{Introduction}

The city of Edwardsport, (Ind.), is a community in Knox County, with an estimated population of 303 (U.S. Census Bureau, 2010). Edwardsport and the surrounding area have experienced flooding numerous times, most recently in 2002, 2005, 2008, and 2013. The majority of flood damages in the Edwardsport area have occurred along the White River, which flows on the east side of the town (Federal Emergency Management Agency, 1984). During flood events, some evacuations are necessary in low areas in the northeast part of the city and some local roads are impassable. Another potential problem from flooding is the halting of rail traffic to the power-generating plant on the south side of town and flooding in parts of the plant property. In addition, agricultural lands surrounding the city have potential for flooding as the levees are topped. Flood plains along the river are moderately developed and contain a mix of residential, commercial, and agricultural areas.

Before this study, emergency responders in Edwardsport relied on several information sources to make decisions on how to best alert the public and mitigate flood damages. One source is the Federal Emergency Management Agency (FEMA) flood insurance study (FIS) for Knox County (Federal Emergency Management Agency, 1984). Another source of information is U.S. Geological Survey_(USGS) streamgage 03360730, White River near Edwardsport, Ind., from which current (U.S. Geological Survey, 2014a) and historical (U.S. Geological Survey, 2014b) water levels (stage) can be obtained (http://nwis.waterdata.usgs.gov/in/nwis/ nwisman/?site_no=03360730\&agency_cd=USGS). A third source is the National Weather Service's (NWS) forecast of peak stage at USGS streamgage 03360730, White River near Edwardsport, Ind., through their Advanced Hydrologic Prediction Service (AHPS) Web site http:/water.weather.gov/ahps/ (National Weather Service, 2014a). 
Although the current stage at a USGS streamgage is particularly useful for residents in the immediate vicinity of a streamgage, it is of limited use to residents farther upstream or downstream because the water-surface elevation is not constant along the entire stream reach. Knowledge of a water level at a streamgage is difficult to translate into depth and areal extent of flooding at points distant from the streamgage. One way to address these informational gaps is to produce a library of flood-inundation maps that are referenced to the stages recorded at the USGS streamgage. By referring to the appropriate map, emergency responders can discern the severity of flooding (depth of water and areal extent); identify roads that are, or will soon be, flooded; and make plans for notification or evacuation of residents in harm's way for some distance upstream and downstream from the streamgage. In addition, the capability to visualize the potential extent of flooding has been shown to motivate residents to take precautions and heed warnings that they previously might have disregarded. In 2013-14, the USGS, in cooperation with the Indiana Department of Transportation, lead a project to produce a library of flood-inundation maps for the White River near Edwardsport, Ind.

\section{Purpose and Scope}

This report describes the development of a series of estimated flood-inundation maps for the White River near Edwardsport, Ind., and identifies where on the Internet the maps can be accessed and ancillary data (geographic information system [GIS] flood polygons and depth grids) can be downloaded. Internet users can select estimated inundation maps that correspond to (1) flood stages at USGS streamgage 03360730 and (2) the NWS forecasted peak stage at the NWS sites FREI3 and EDWI3.The scope of the study was limited to the White River reach extending 2.4 miles (mi) upstream from USGS streamgage 03360730 at the State Road 358 Bridge and 0.94 mi downstream from streamgage 03360730 (fig. 1).

The flood-inundation maps were produced for flood levels referenced to the stage recorded at the USGS streamgage 03360730 on the White River near Edwardsport, Ind. (table 1); the streamgage is on the downstream side of the State Road 358 bridge. The maps cover a range in stage from 12 to 29.9 feet (ft). The 12 -ft stage is approximately bankfull and is defined by the National Weather Service (2014b) as the "action stage" or that stage which, when reached by a rising stream, requires the NWS or a partner to take some type of mitigation action in preparation for possible significant hydrologic activity. The 29.9-ft stage is the highest stage on the current (2014) stage-discharge rating curve. The stage of the flood of April 24, 2013, near Edwardsport, was $25.4 \mathrm{ft}$ (U.S. Geological Survey, 2014c). The major flood stage, as determined by the NWS, is $25 \mathrm{ft}$.

\section{Study Area Description}

The White River near the city of Edwardsport is in southwest Indiana in the Wabash Lowland physiographic section of the Southern Hills and Lowlands Region (Gray, 2000). The drainage area is 4,988 square miles $\left(\mathrm{mi}^{2}\right)$ at the upstream end of the study reach; 5,015 $\mathrm{mi}^{2}$ at USGS streamgage 03360730 (White River near Edwardsport); and 5,016 $\mathrm{mi}^{2}$ at the downstream extent of the study reach (U.S. Geological Survey, 2014a, 2014d). The headwaters originate in Randolph County (not shown) and the stream flows generally southwestward entering the town of Edwardsport. There are no significant tributaries to the White River as it flows through the study reach. Generally, the area has extensive flood plains with broad terraces and is underlain by outwash sand. The study reach is approximately $3.3 \mathrm{mi}$ long and has an average topof-bank channel width of about $350 \mathrm{ft}$ and an average channel slope of 0.0002 (1.2 feet per mile [ft/mi]). Most of the land contiguous to the study reach is either agricultural or natural areas with much smaller portions having residential development. An earthen levee (shown as "levee" on fig. 1) runs along the eastern bank of the study area. The levee protects the agricultural area from flooding until it is overtopped during the highest flows (at stage $27 \mathrm{ft}$ and above). There is also an earthen embankment that runs along the western bank from State Road 358 southward and past the study extent. The overall effectiveness of this embankment is unknown; therefore, it was not simulated as a levee in the hydraulic model that was developed for this study.

The population of Edwardsport has declined in recent years from 363 in 2000 to 303 in 2010 (U.S. Census Bureau, 2010). The main channel within the study reach has one major road crossing, State Road 358, crossing the main channel and adjacent flood plain. A railroad spur enters the town from the north and runs along the west side of the river. This spur serves the power generating facility on the south side on Edwardsport. This railroad, a small part of the power generating facility, and local roads close to the river are vulnerable to flooding during the highest flows.

\section{Previous Studies}

The most recent FIS for Knox County (Federal Emergency Management Agency, 1984) is a study that investigated the existence and severity of flood hazards in the unincorporated areas of Knox County. The FIS presents estimates of the peak discharges with 10-, 2-, 1-, and 0.2-percent annual exceedance probabilities and their associated water-surface elevations for the White River at Petersburg (03373980) (river mile 45.7) (http://nwis.waterdata.usgs.gov/in/nwis/ uv/?site_no=03373980). 


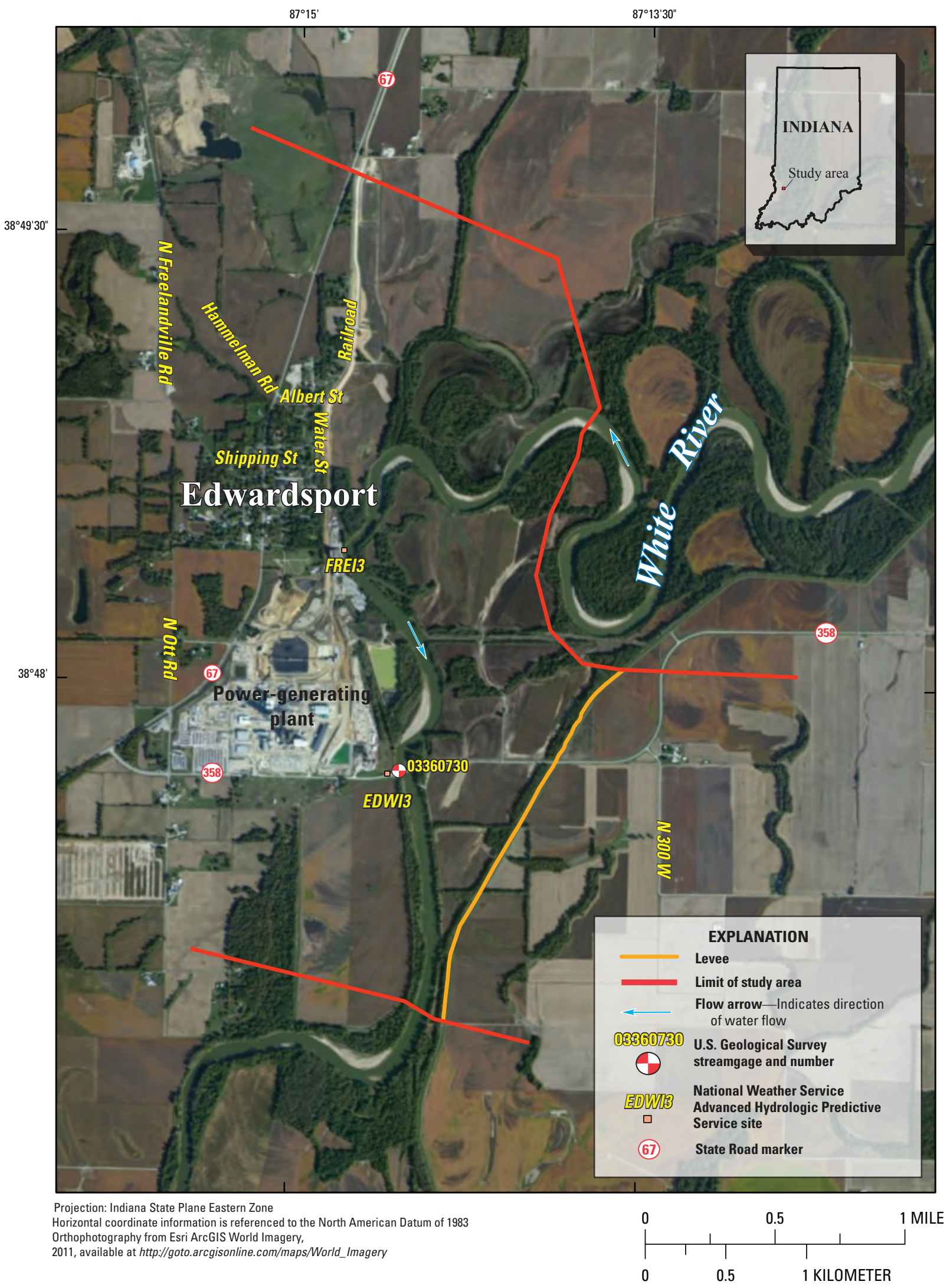

Figure 1. Location of study reach for the White River near Edwardsport, Indiana; location of U.S. Geological Survey streamgage; and location of National Weather Service forecast sites (FREI3 and EDWI3). 
Table 1. U.S. Geological Survey streamgage information for White River near Edwardsport, Indiana (station number 03360730).

$\left[\mathrm{mi}^{2}\right.$, square miles; NAD 27, North American Datum of 1927; ' , degree; ', minutes; ", seconds; NAVD 88, North American Vertical Datum of 1988 ; ft, feet; ft³/s, cubic feet per second]

\begin{tabular}{|c|c|c|c|c|c|c|c|c|}
\hline $\begin{array}{c}\text { Streamgage } \\
\text { name }\end{array}$ & $\begin{array}{c}\text { Streamgage } \\
\text { number }\end{array}$ & $\begin{array}{c}\text { Drainage } \\
\text { area } \\
\left(\mathrm{mi}^{2}\right)\end{array}$ & $\begin{array}{l}\text { Latitude } \\
\text { (NAD 27) }\end{array}$ & $\begin{array}{c}\text { Longitude } \\
\text { (NAD 27) }\end{array}$ & $\begin{array}{l}\text { Period } \\
\text { of record }\end{array}$ & $\begin{array}{c}\text { Datum } \\
\text { of gage } \\
\text { (NAVD 88) }\end{array}$ & $\begin{array}{l}\text { Maximum } \\
\text { recorded flood } \\
\text { elevation } \\
\text { (NAVD 88) } \\
\text { and date }\end{array}$ & $\begin{array}{c}\text { Maximum } \\
\text { discharge, } \\
\text { in } \mathrm{ft}^{3} / \mathrm{s}, \\
\text { and date }\end{array}$ \\
\hline $\begin{array}{l}\text { White River near } \\
\text { Edwardsport, } \\
\text { Indiana }\end{array}$ & 03360730 & 5,015 & $38^{\circ} 47^{\prime} 42.2^{\prime \prime}$ & $87^{\circ} 14^{\prime} 30.7^{\prime \prime}$ & $\begin{array}{c}\text { August } 2012 \\
\text { to present }\end{array}$ & $431.56 \mathrm{ft}$ & $\begin{array}{l}456.96 \mathrm{ft} \text { on } \\
\text { April 24, } 2013 \\
\text { (corresponds } \\
\text { to a gage } \\
\text { height of } \\
25.40 \mathrm{ft} \text { ) }\end{array}$ & $\begin{array}{l}\text { 61,400 on } \\
\text { April 24, } \\
2013 .\end{array}$ \\
\hline
\end{tabular}

The USGS streamgage near Edwardsport is at river mile 81 and does not compare well to the discharges at the Petersburg streamgage; however, the FIS does include information about the principal flood problems in Knox County.

The Indiana Department of Natural Resources (IDNR) has produced Digital Flood Insurance Rate Maps (DFIRM) that include the study area in both Knox and Daviess Counties (Indiana Department of Natural Resources, 2004a and 2004b). These maps outline the special flood hazard areas around Edwardsport. In addition, IDNR, the USGS, the Natural Resource Conservation Service, and the U.S. Army Corps of Engineers have agreed to the discharge-frequency values for sites along many rivers in Indiana, the values are termed coordinated discharges and assure consistency among the State and Federal agencies that undertake streamflow studies (Indiana Department of Natural Resources, 2014). The coordinated discharges for the White River near Edwardsport are listed in table 2.

Table 2. Coordinated discharges for selected annual exceedance probabilities for White River near Edwardsport, Indiana.

$\left[\mathrm{mi}^{2}\right.$, square miles; $\mathrm{ft}^{3} / \mathrm{s}$, cubic feet per second; USGS, U.S. Geological Survey]

\begin{tabular}{lcccc}
\hline $\begin{array}{l}\text { Location on } \\
\text { White River }\end{array}$ & $\begin{array}{c}\text { Drainage } \\
\text { area } \\
\left(\mathbf{m i}^{2}\right)\end{array}$ & $\begin{array}{c}\text { Coordinated discharges }\left(\mathbf{f t}^{3} / \mathbf{s}\right) \text { for } \\
\text { indicated annual exceedance } \\
\text { probabilities (in percent) }\end{array}$ \\
\hline & & $\mathbf{1 0}$ & $\mathbf{2}$ & $\mathbf{1}$ \\
\cline { 2 - 5 } $\begin{array}{l}\text { At USGS } \\
\text { streamgage } \\
\text { number 03360730 }\end{array}$ & 5,015 & 67,500 & 95,100 & 109,000 \\
\hline
\end{tabular}

\footnotetext{
${ }^{1}$ Data from USGS StreamStats (2014).
}

\section{Creation of Flood-Inundation Map Library}

The USGS has standardized the procedures for creating flood-inundation maps for flood-prone communities so that the process followed and products produced are similar regardless of which USGS office is responsible for the work (U.S. Geological Survey, 2014e). Tasks specific to development of the flood maps for Edwardsport, Ind., were (1) installation of the streamgage on the White River near Edwardsport in 2012 (table 1), (2) collection of topographic and bathymetric data for selected cross sections and geometric data for structures and bridges along the study reach, (3) estimation of energyloss factors (roughness coefficients) in the stream channel and flood plain and determination of steady-flow data, (4) collection of high-water marks for the flood of 2013, (5) computation of water-surface profiles using the U.S. Army Corps of Engineers' HEC-RAS computer program (U.S. Army Corps of Engineers, 2010), (6) production of estimated flood-inundation maps at various stream stages using the U.S. Army Corps of Engineers' HEC-GeoRAS computer program (U.S. Army Corps of Engineers, 2009) and a GIS, and (7) preparation of the maps, both as shapefile polygons that depict the areal extent of flood inundation and as depth grids that provide the depth of floodwaters, for display on a USGS flood-inundation mapping application. 


\section{Computation of Water-Surface Profiles}

The water-surface profiles used to produce the 19 flood-inundation maps in this study were simulated by using HEC-RAS, version 4.1.0 (U.S. Army Corps of Engineers, 2010). HEC-RAS is a one-dimensional step-backwater model for simulation of water-surface profiles with gradually varied, steady-state or unsteady-state flow computation options. The HEC-RAS analysis for this study was done using the steadystate flow computation option.

\section{Hydrologic Data}

The study area hydrologic network consists of one streamgage 03360730 (fig. 1; table 1), which has been in operation since August 2012. This streamgage has a continuous record of measured water level (stage) and computed streamflow since 2012. Stage is measured every 15 minutes, transmitted hourly by a satellite radio in the streamgage, and made available on the Internet through the USGS National Water Information System (NWIS; U.S. Geological Survey, 2014b).
Stage data from this streamgage are referenced to a local datum but can be converted to water-surface elevations referenced to the North American Vertical Datum of 1988 (NAVD 88 ) by adding $431.56 \mathrm{ft}$. Continuous records of streamflow are computed from a stage-discharge relation, which has been developed for the streamgage, and are available through the USGS NWIS Web site (http://waterdata.usgs.gov/nwis).

The steady-flow data necessary for the hydraulic model consisted of boundary conditions (normal depth) and peakdischarge information. The peak flows used in the model simulations (table 3) were taken from the current stage-discharge relation (USGS rating no. 3, effective May 30, 2014) and corresponded with the target stages. The steady-flow data for the model were obtained from field measurements of streamflow at USGS streamgage 03360730, White River near Edwardsport, Ind. All computations used discharge values with known stages from actual streamflow measurements or the stage-discharge relations at the gage. No major tributaries join the White River within the 3.3-mi study reach; therefore, the gage-derived discharges were not adjusted for tributary inflows but were held constant throughout the study reach for a given profile (table 3 ).

Table 3. Estimated discharges for corresponding stages and water-surface elevations at U.S. Geological Survey streamgage 03360730 used in the hydraulic model of the White River near Edwardsport, Indiana.

[mi², square miles; $\mathrm{ft}^{3} / \mathrm{s}$, cubic feet per second; NAVD 88, North American Vertical Datum of 1988]

\begin{tabular}{|c|c|c|c|c|c|c|c|c|c|c|c|c|}
\hline \multirow[b]{2}{*}{ Location } & \multirow[b]{2}{*}{$\begin{array}{c}\text { Drainage } \\
\text { area } \\
\left(\mathrm{mi}^{2}\right)\end{array}$} & \multicolumn{11}{|c|}{ Stage, in feet above gage datum at White River (reference datum 431.56 NAVD 88) } \\
\hline & & $\begin{array}{c}12.0 \\
(443.56)\end{array}$ & $\begin{array}{c}13.0 \\
(444.56)\end{array}$ & $\begin{array}{c}14.0 \\
(445.56)\end{array}$ & $\begin{array}{c}15.0 \\
(446.56)\end{array}$ & $\begin{array}{c}16.0 \\
(447.56)\end{array}$ & $\begin{array}{c}17.0 \\
(448.56)\end{array}$ & $\begin{array}{c}18.0 \\
(449.56)\end{array}$ & $\begin{array}{c}19.0 \\
(450.56)\end{array}$ & $\begin{array}{c}20.0 \\
(451.56)\end{array}$ & $\begin{array}{c}21.0 \\
(452.56)\end{array}$ & $\begin{array}{c}22.0 \\
(453.56)\end{array}$ \\
\hline \multirow{5}{*}{$\begin{array}{l}\text { Streamgage } \\
\text { number } \\
03360730\end{array}$} & \multirow{5}{*}{5,015} & \multicolumn{11}{|c|}{ Discharge $\left(\mathrm{ft}^{3} / \mathrm{s}\right)$} \\
\hline & & 9,820 & 11,300 & 12,800 & 14,400 & 16,100 & 17,800 & 19,800 & 23,200 & 27,600 & 32,600 & 38,100 \\
\hline & & \multicolumn{11}{|c|}{ Stage, in feet above gage datum at White River (reference datum 431.56 NAVD 88) } \\
\hline & & \multicolumn{11}{|c|}{ Discharge $\left(\mathrm{ft}^{3} / \mathrm{s}\right)$} \\
\hline & & 44,200 & 50,900 & 58,300 & 66,300 & 75,500 & 87,100 & 99,900 & 113,000 & & & \\
\hline
\end{tabular}




\section{Topographic and Bathymetric Data}

All topographic data used in this study are referenced vertically to NAVD 88 and horizontally to the North American Datum of 1983 (NAD 83). Cross-section elevation data were obtained from a digital elevation model (DEM) that was derived from light detection and ranging (lidar) data that were collected as part of a statewide project during 2011-13 by Woolpert, Inc., Geospatial Services, Dayton, Ohio (Woolpert, Inc., 2011). The lidar data for Knox and Daviess Counties were collected in 2013. The DEM was obtained from the Indiana Spatial Data Portal (Indiana University, 2013). The original lidar data have horizontal resolution of $4.9 \mathrm{ft}$ and vertical accuracy of $0.98 \mathrm{ft}$ at a 95 -percent confidence level based on a root mean squared error of $0.49 \mathrm{ft}$ for the "open terrain" land-cover category. By these criteria, the lidar data support production of 2-ft contours (Dewberry, 2012); the final DEM, which was resampled to a grid-cell size of $10 \mathrm{ft}$ by 10 $\mathrm{ft}$ to decrease the GIS processing time, has a vertical accuracy of plus or minus $1 \mathrm{ft}$. By using HEC-GeoRAS (a set of procedures, tools, and utilities for processing geospatial data in ArcGIS) elevation data were extracted from the DEM for 33 cross sections, including one bridge, and a levee to protect the agricultural area on the east side of the study area from flooding. These data subsequently were input to the HEC-RAS model.

Because lidar data cannot provide ground elevations below a stream's water surface, channel cross sections were surveyed by USGS field crews during 2013. Cross-sectional depths were measured by using hydroacoustic instrumentation at 18 locations. A differential global positioning system (DGPS) with real-time kinematic (RTK) technology was used to derive horizontal locations and the elevation of the water surface at each surveyed cross section.

In the ArcMap application of ArcGIS (Esri, 2014), these field data were used in conjunction with a bathymetry mesh tool, created by Merwade and others (2008), to interpolate below-water ground elevations through the study reach. The density of ground elevations in the mesh was determined by two variables: (1) the number of parallel longitudinal profiles that were evenly spaced across the channel and ran the length of the study reach, and (2) the user-specified spacing between cross sections. Ground elevations were either extracted or interpolated from the field data at the intersections of the longitudinal profiles and cross sections that were spaced approximately $500 \mathrm{ft}$ apart. The mesh elevations were subsequently added to the DEM data of the synthetic cross sections before the data were exported to HEC-RAS. Instructions for the bathymetry mesh tool are presented by Merwade (2011).

\section{Hydraulic Structures}

There is one road (State Road 358) crossing that has the potential to affect water-surface elevations during floods along the stream. Bridge-geometry data were obtained from field surveys conducted by USGS personnel (C.D. Menke, unpub. data, 2013). A levee exists along the east side of the study area and provides protection from flooding in the adjacent croplands. An earthen embankment runs along the west bank of the White River downstream from the bridge and continues past the study extent. Because of the uncertainty as to the effectiveness of this embankment, it was not simulated as a levee; rather, where appropriate to do so, the landward side of the levee was simulated as ineffective flow area up to the elevation of the top of the embankment.

\section{Energy-Loss Factors}

Hydraulic analyses require the estimation of energy losses that result from frictional resistance exerted by a channel on flow. These energy losses are quantified by the Manning's roughness coefficient ( $n$-value) (Arcement and Schneider, 1989). Initial (pre-calibration) $n$-values were selected on the basis of field observations and high-resolution aerial photographs. An $n$-value of 0.040 was selected for the main channel and 0.100 for the overbank areas, which are dominated by forests and agricultural fields in the rural sections of the study reach and a small residential and commercial areas within the city of Edwardsport.

The initial $n$-values were adjusted as part of the calibration process, which involved stepwise matching of simulated and observed water-surface elevations, starting at the downstream end of the study reach and moving upstream. Roughness-coefficient adjustment factors were varied by flow and adjusted until the simulated water-surface elevations approximated the observed water-surface elevations in the downstream half of the study reach (upstream from the bridge on State Road 358). The actual $n$-values were computed by multiplying the initial $n$-value by each of the roughnesscoefficient adjustment factors. Main channel $n$-values ranged from 0.040 to 0.049 , and overbank values ranged from 0.088 to 0.11 . Upstream from the bridge to the upstream end of the study reach, $n$-values were no longer varied by discharge. Again, these values were used, and transitions were made, to minimize the differences between simulated and observed high-water marks. 


\section{Hydraulic Model}

The HEC-RAS analysis for this study was done by using the steady-state flow computation option. Steady-state flow data consisted of flow regime, boundary conditions, and peak flows that produced water-surface elevations at the streamgage cross section that matched target water-surface elevations. These target elevations coincided with even 1 - $\mathrm{ft}$ increments of stage, referenced to the local streamgage datum. Subcritical (tranquil) flow regime was assumed for the simulations. Normal depth based on an estimated average channel slope of 0.0002 from data obtained from a USGS field crew in 2013 (C.D. Menke, unpub. data) was used as the downstream boundary condition of the reach. The peak flows that were used in the model were discussed in the "Hydrologic Data" section.

The hydraulic model was calibrated to the most current stage-discharge relation (USGS rating no. 3, May 30, 2014) at USGS streamgage 03360730, White River near Edwardsport, Ind., and high-water marks from the flood of April 24, 2013. Model calibration was accomplished by adjusting Manning's $n$-values until the results of the hydraulic computations closely agreed with the observed water-surface elevations for given flows. Differences between target and modeled water-surface elevations for the 19 simulated flows at the USGS streamgage 03360730 were equal to or less than $0.20 \mathrm{ft}$ (table 4). Differences between surveyed and modeled elevations of high-water marks in the study reach for the flood of April 24, 2013, were equal to or less than $0.18 \mathrm{ft}$ (table 5). The results demonstrate that the model is capable of simulating accurate water levels over a wide range of flows in the basin.
Table 4. Calibration of hydraulic model to target water-surface elevations at U.S. Geological Survey streamgage on White River near Edwardsport, Indiana (station number 03360730)

[ft, feet; NAVD 88, North American Vertical Datum of 1988]

\begin{tabular}{|c|c|c|c|}
\hline $\begin{array}{c}\text { Stage of } \\
\text { water-surface } \\
\text { profile } \\
\text { (ft) }\end{array}$ & $\begin{array}{c}\text { Target } \\
\text { water-surface } \\
\text { elevation } \\
\text { (ft, NAVD 88) }\end{array}$ & $\begin{array}{c}\text { Modeled } \\
\text { water-surface } \\
\text { elevation } \\
\text { (ft, NAVD 88) }\end{array}$ & $\begin{array}{c}\text { Elevation } \\
\text { difference } \\
\text { (ft) }\end{array}$ \\
\hline 12.00 & 443.56 & 443.67 & 0.11 \\
\hline 13.00 & 444.56 & 444.71 & 0.15 \\
\hline 14.00 & 445.56 & 445.69 & 0.13 \\
\hline 15.00 & 446.56 & 446.69 & 0.13 \\
\hline 16.00 & 447.56 & 447.64 & 0.08 \\
\hline 17.00 & 448.56 & 448.54 & -0.02 \\
\hline 18.00 & 449.56 & 449.47 & -0.09 \\
\hline 19.00 & 450.56 & 450.46 & -0.10 \\
\hline 20.00 & 451.56 & 451.37 & -0.19 \\
\hline 21.00 & 452.56 & 452.47 & -0.09 \\
\hline 22.00 & 453.56 & 453.38 & -0.18 \\
\hline 23.00 & 454.56 & 454.41 & -0.15 \\
\hline 24.00 & 455.56 & 455.47 & -0.09 \\
\hline 25.00 & 456.56 & 456.57 & 0.01 \\
\hline 26.00 & 457.56 & 457.42 & -0.14 \\
\hline 27.00 & 458.56 & 458.71 & 0.15 \\
\hline 28.00 & 459.56 & 459.36 & -0.20 \\
\hline 29.00 & 460.56 & 460.39 & -0.17 \\
\hline 29.90 & 461.46 & 461.31 & -0.15 \\
\hline
\end{tabular}

Table 5. Calibration of hydraulic model to water-surface elevations at selected locations along the White River for the flood of April 24, 2013.

[ ft, feet; NAVD 88, North American Vertical Datum of 1988]

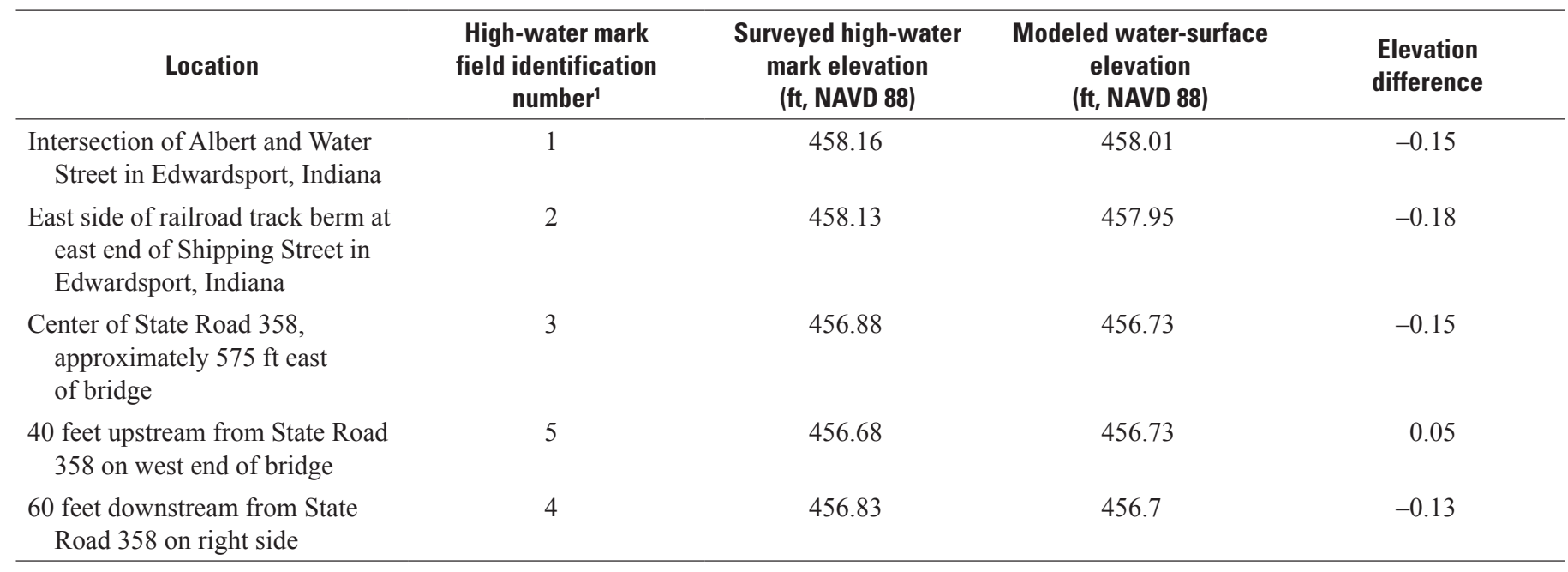

${ }^{1}$ U.S.Geological Survey field survey of high-water marks for the flood of April 24, 2013, collected April 26, 2013. 


\section{Development of Water-Surface Profiles}

The calibrated hydraulic model was used to generate water-surface profiles for a total of 19 stages at approximately 1 - $\mathrm{ft}$ intervals between $12 \mathrm{ft}$ and $29.9 \mathrm{ft}$ as referenced to USGS streamgage 03360730, White River near Edwardsport, Ind. Discharges corresponding to the various stages were obtained from the most current stage-discharge relation (USGS rating no. 3, May 30, 2014) at USGS streamgage 03360730 , White River near Edwardsport, Ind. Calibration of the model was also aided by the collection of high-water marks from the flood of April 24, 2013.

Discharges for all profiles (table 3) were selected with the assumption that there are no significant tributary or groundwater inflows within the 3.3-mi study reach. The discharges were estimated to be uniform and steady throughout the study reach.

\section{Development of Flood-Inundation Maps}

Flood-inundation maps were created for a reach of the White River near Edwardsport, Ind. The maps were created in a GIS by combining the 19 water-surface profiles and digital elevation model data. The DEM data were derived from the same lidar data described previously in the "Topographic and Bathymetric Data" section and therefore have an estimated vertical accuracy of $2 \mathrm{ft}$ (that is, plus or minus $1 \mathrm{ft}$ ). Estimated flood-inundation boundaries for each simulated profile were developed with HEC-GeoRAS software (U.S. Army Corps of Engineers, 2009), which allows the preparation of geometric data for import into HEC-RAS and processes simulation results exported from HEC-RAS (U.S. Army Corps of Engineers, 2010). Shapefile polygons and depth grids of the inundated areas for each profile were modified, as required, in the ArcMap application of ArcGIS to ensure a hydraulically reasonable transition of the flood boundaries between modeled cross sections.

Any inundated areas that were detached from the main channel were examined to identify subsurface connections with the main river, such as through culverts under roadways. Where such connections existed, the mapped inundated areas were retained in their respective flood maps; otherwise, the erroneously delineated parts of the flood extent were deleted. The flood-inundation areas are overlaid on high-resolution, geo-referenced, aerial photographs of the study area. Bridge surfaces are displayed as inundated regardless of the actual water-surface elevation in relation to the lowest structural chord of the bridge or the bridge deck.

Estimates of water depth can be obtained from the depthgrid data that are included with the presentation of the flood maps on an interactive USGS mapping application described in the following section. The flood-inundation map corresponding to the highest simulated water-surface profile, a stage of $29.9 \mathrm{ft}$, is presented in figure 2 .

\section{Flood-Inundation Map Delivery}

A Flood Inundation Mapping Science Web site (U.S. Geological Survey, 2014d) has been established to make USGS flood-inundation study information available to the public; that site links to a mapping application that presents map libraries and provides detailed information on flood extents and depths for modeled sites. The mapping application enables the production of customized flood-inundation maps from the map library for White River near Edwardsport, Ind. A link on this Web site connects to the USGS NWIS (U.S. Geological Survey, 2014a), which presents the current stage and streamflow at the USGS streamgage 03360730 to which the flood-inundation maps are referenced. A second link connects to the NWS AHPS site (National Weather Service, 2014a) so that the user can obtain applicable information on forecasted peak flows. The estimated flood-inundation maps are displayed in sufficient detail so that preparations for flooding and decisions for emergency response can be performed efficiently. Depending on the flood magnitude, roadways are shown as shaded (inundated and likely impassable) or not shaded (dry and passable) to facilitate emergency planning and use. Above a stage of $18 \mathrm{ft}$, the levee on the east side of the river becomes effective and is shown with green shading. The levee is shown as overtopped at $27 \mathrm{ft}$. Bridges are shaded (that is, shown as inundated) regardless of the flood magnitude. A shaded building should not be interpreted to indicate that the structure is completely submerged, rather that bare earth surfaces in the vicinity of the building are inundated. In these instances, the water depth (as indicated in the mapping application by holding the cursor over an inundated area) near the building would be an estimate of the water level inside the structure, unless flood-proofing measures had been implemented.

\section{Disclaimer for Flood-Inundation Maps}

The flood-inundation maps should not be used for navigation, regulatory, permitting, or other legal purposes. The USGS provides these maps "as is" for a quick reference, emergency planning tool but assumes no legal liability or responsibility resulting from the use of this information. 


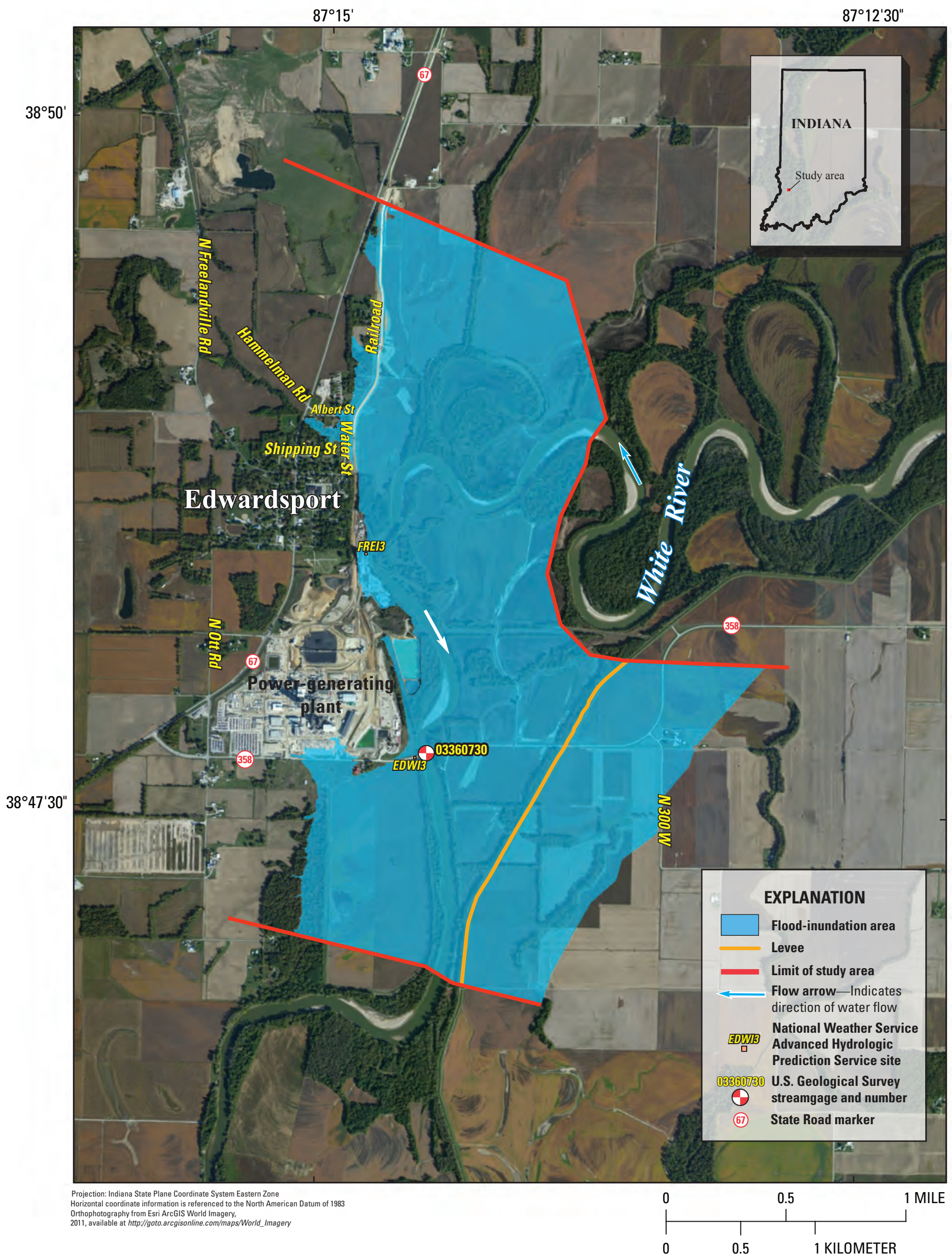

Figure 2. Flood-inundation map for the White River near Edwardsport, Indiana, corresponding to a stage of 29.9 feet at the U.S. Geological Survey streamgage (station number 03360730). 


\section{Uncertainties and Limitations Regarding Use of Flood-Inundation Maps}

Although the flood-inundation maps represent the boundaries of inundated areas with a distinct line, some uncertainty is associated with these maps. The flood boundaries shown were estimated on the basis of water stages and streamflows at selected USGS streamgages. Water-surface elevations along the stream reaches were estimated by steady-state hydraulic modeling, assuming unobstructed flow, and using streamflows and hydrologic conditions anticipated at the USGS streamgage. The hydraulic model reflects the land-cover characteristics and any bridge, dam, levee, or other hydraulic structures existing as of March 2013. Unique meteorological factors (timing and distribution of precipitation) may cause actual streamflows along the modeled reach to vary from those assumed during a flood, which may lead to deviations in the water-surface elevations and inundation boundaries shown. Additional areas may be flooded because of unanticipated conditions such as changes in the streambed elevation or roughness, backwater into major tributaries along a main stem river, or backwater from localized debris or ice jams. The accuracy of the floodwater extent portrayed on these maps will vary with the accuracy of the DEM used to simulate the land surface.

If this series of flood-inundation maps will be used in conjunction with NWS river forecasts, the user should be aware of additional uncertainties that may be inherent or factored into NWS forecast procedures. The NWS uses forecast models to estimate the quantity and timing of water flowing through selected stream reaches in the United States. These forecast models (1) estimate the amount of runoff generated by precipitation and snowmelt, (2) simulate the movement of floodwater as it proceeds downstream, and (3) predict the flow and stage (and water-surface elevation) for the stream at a given location (AHPS forecast point) throughout the forecast period (every 6 hours and 3 to 5 days in the future in many locations). For more information on AHPS forecasts, please refer to http://water.weather.gov/ahps/forecasts.php.

An additional source of uncertainty is pertinent to the White River near Edwardsport. The flood maps show a levee east of the river and midway to the east side of the study area that is to protect agricultural areas from flooding. The extent and depth of flooding that occur on the landward side of this levee are uncertain, yet the fields are shown as inundated at the $29.9 \mathrm{ft}$ stage (fig. 2). The extent and depth of flooding will vary with the elevation of the water surface in the river and the length of time that the water level remains above the elevation of low spots on the levee. Because the actual extent and depth of flooding in these leveed areas during a particular flood event are uncertain, the flood-inundation maps show flooding as the "worst-case" scenario (that is, the maximum flood extent that would occur if the levee did not exist). The "areas of uncertainty due to a levee" are displayed in green to reflect this uncertainty and in blue when a levee is circumvented or overtopped. Additional uncertainties and limitations pertinent to this study may be described elsewhere in this report.

\section{Summary}

A series of 19 digital flood-inundation maps were developed in cooperation with the Indiana Department of Transportation for the White River near Edwardsport from 2.4 miles (mi) upstream from the U.S. Geological Survey (USGS) streamgage 03360730 at the State Road 358 bridge to $0.94 \mathrm{mi}$ downstream from the streamgage. The flood-inundation maps were developed by using the U.S. Army Corps of Engineers' HEC-RAS and HEC-GeoRAS programs to compute water-surface profiles and to delineate estimated floodinundation areas and depths of flooding for selected stream stages. The HEC-RAS hydraulic model was calibrated to the current stage-discharge relation at the White River streamgage and to the flood of April 2013. The model was used to compute 19 water-surface profiles for flood stages at approximately 1 -foot intervals referenced to the streamgage datum and ranging from $12 \mathrm{ft}$, or near bankfull, to $29.9 \mathrm{ft}$, which is the highest stage of the stage-discharge rating. The simulated water-surface profiles were then combined with a geographic information system digital elevation model derived from light detection and ranging (lidar) data to delineate estimated floodinundation areas as shapefile polygons and depth grids for each profile. These flood-inundation polygons were overlaid on high-resolution, geo-referenced, aerial photographs of the study area. The flood maps are available through a mapping application that can be accessed on the USGS Flood Inundation Mapping Science Web site (http://water.usgs.gov/osw/ flood_inundation).

Interactive use of the maps on the USGS mapping application can give users a general indication of depth of water at any point by using the mouse cursor to click within the shaded areas. The mapping application enables the production of customized flood-inundation maps from the map library for White River near Edwardsport, Indiana. These maps, in conjunction with the real-time stage data from the USGS streamgage, White River near Edwardsport, Ind. (station number 03360730), and forecasted flood stage data from the National Weather Service Advanced Hydrologic Prediction Service, will help to guide the general public in taking individual safety precautions and will provide emergency management personnel with a tool to efficiently manage emergency flood operations and post-flood recovery efforts. 


\section{References Cited}

Arcement, G.J., and Schneider, V.R., 1989, Guide for selecting Manning's roughness coefficients for natural channels and flood plains: U.S. Geological Survey Water-Supply Paper $2339,38 \mathrm{p}$.

Dewberry, 2012, Final Report of the National Enhanced Elevation Assessment: Fairfax, Va., Dewberry, 84 p. plus appendixes, available at http://www.dewberry.com/services/ geospatial/national-enhanced-elevation-assessment.

Esri, 2014, ArcGIS, accessed July 2014, at http://www.esri. com/software/arcgis/.

Federal Emergency Management Agency, 1984, Flood insurance study, Knox County, Indiana, and unincorporated areas: Washington D.C., 19 p., 7 pls.

Gray, H.H., 2000, Physiographic divisions of Indiana: Bloomington, Ind., Indiana Geological Survey Special Report 61, 15 p., 1 pl.

Indiana Department of Natural Resources, 2004a, DFIRM database, Knox County, Indiana, USA, available at http://www.in.gov/dnr/water/3484.htm.

Indiana Department of Natural Resources, 2004b, DFIRM database, Daviess County, Indiana, USA, available at http://www.in.gov/dnr/water/6281.htm.

Indiana Department of Natural Resources, 2014, Coordinated discharges of selected streams in Indiana, accessed January 2014, at http://www.in.gov/dnr/water/4898.htm.

Indiana University, 2013, Indiana spatial data portal, accessed March 2014 at http://gis.iu.edu/.

Merwade, V., 2011, Creating bathymetry mesh from cross sections: Purdue University, School of Civil Engineering, accessed March 2013 at http://web.ics.purdue. edu/ vmerwade/research/bathymetry_tutorial.pdf.

Merwade, V., Cook, A., and Coonrod, J., 2008, GIS techniques for creating river terrain models for hydrodynamic modeling and flood inundation mapping: Environmental Modelling and Software, v. 23, no. 10-11, p. 1300-1311.

National Weather Service, 2014a, Advanced hydrologic prediction service, White River near Edwardsport, Indiana 03360730 (EDWI3), accessed June 2014 at http://water. weather.gov/ahps $2 /$ index.php?wfo=indEdwardsport.
National Weather Service, 2014b, National Weather Service glossary, accessed June 2013, at http://w1.weather.gov/glossary/index.php? word=action+stage.

U.S. Army Corps of Engineers, Hydrologic Engineering Center, 2011, HEC-GeoRAS, GIS tools for support of HEC-RAS using ArcGIS, user's manual, [variously paged], accessed June 2013, at http://www.hec.usace.army.mil/software/hec-georas/documentation/HEC-GeoRAS_43_Users_ Manual.pdf.

U.S. Army Corps of Engineers, Hydrologic Engineering Center, 2010, HEC-RAS river analysis system, hydraulic reference manual, version 4.1, [variously paged], accessed June 2013, at http://www.hec.usace.army.mil/software/hecras/documentation/HEC-RAS_4.1_Reference_Manual.pdf.

U.S. Census Bureau, 2010, 2010 Census interactive population search IN- Edwardsport town: Washington, D.C., accessed March 2013, at http://www.census.gov/2010census/popmap/ ipmtext.php?fl=18.

U.S. Geological Survey, 2014a, USGS 03360730, White River near Edwardsport, Ind: U.S. Geological Survey, accessed June 2014 at http://nwis.waterdata.usgs.gov/in/nwis/ uv?site_no=03360730.

U.S. Geological Survey, 2014b, USGS surface-water data for the Nation: U.S. Geological Survey, accessed June 2014 at http://nwis.waterdata.usgs.gov/in/nwis/nwisman/?site no $=03360730 \&$ agency_cd $=$ USGS.

U.S. Geological Survey, 2014c, USGS 03360730, White River near Edwardsport, Ind: U.S. Geological Survey, accessed June 2014, at http://nwis.waterdata.usgs.gov/in/nwis/ peak?site_no $=03360730 \&$ agency_cd $=$ USGS\& format $=\mathrm{html}$

U.S. Geological Survey, 2014d, StreamStats for Indiana streams, accessed June 2014 at http://streamstats.usgs.gov/ indiana.html.

U.S. Geological Survey, 2014e, USGS Flood inundation mapping science: U.S. Geological Survey, accessed April 2014 at http://water.usgs.gov/osw/flood_inundation.

Woolpert, Inc., 2011, Woolpert Order No. 71177, Indiana Statewide Imagery and LiDAR Program, remote sensing image: Dayton, Ohio, Woolpert, Inc., metadata available at http://gis.iu.edu/files/documents/in2011_ortho.txt. 




\section{$\frac{\mathbb{3}}{\mathrm{C}}$}

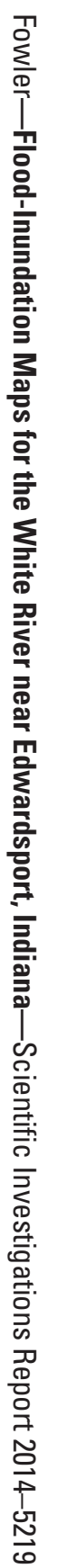

